\title{
ДО 75-РІЧЧЯ ВИДАТНОГО НАУКОВЦЯ
}

5 січня 2015 р. виповнилось 75 років ректору Національного фармацевтичного університету Валентину Петровичу Черних - члену-кореспонденту Національної академії наук України, лауреату Державної премії України, доктору фармацевтичних наук, доктору хімічних наук, професору. 2015 рік знаменний для Валентина Петровича ще й тим, що виповнюється 50 років його науково-педагогічної та громадської діяльності й 35 років на посаді ректора.

Півстоліття життя віддано служінню благородній місії підготовці фахівців для фармацевтичної галузі, а також наукових і науково-педагогічних кадрів, розбудові та реорганізації Національного фармацевтичного університету, головного фармацевтичного вищого навчального закладу України з історією, яка починається в далекому 1805 р., реформуванню вищої фармацевтичної освіти і фармацевтичної галузі України.

В. П. Черних пройшов шлях від студента, аспіранта, асистента, доцента, професора, завідувача кафедри, декана, проректора 3 навчальної роботи до ректора Національного фармацевтичного університету, який очолює з 1980 р.

Під керівництвом В. П. Черних Харківський фармацевтичний інститут пройшов складні етапи реорганізації від невеликого маловідомого інституту до найбільшого Національного фармацевтичного університету, який відповідає найвищим державним і міжнародним критеріям.

Сьогодні колектив університету налічує понад 20 тисяч співробітників і студентів. Під керівництвом видатного організатора Харківський фармацевтичний інститут, в якому навчалися 1600 студентів за однією спеціальністю «Фармація» та працювали 6 докторів наук і 73 кандидати наук, виріс в унікальний науково-освітній комплекс - Національний фармацевтичний університет, в якому сьогодні навчаються 17500 студентів за 14 спеціальностями та займаються науково-педагогічною діяльністю 110 докторів наук і 500 кандидатів наук, середній вік яких становить 45 років. у 1991 р. Харківський фармацевтичний інститут одним із перших серед 900 ВНЗ отримав статус акредитованого на союзному рівні. У 1999 р. у першій п'ятірці ВНЗ України набув статусу національного, став другим національним вищим навчальним закладом у м. Харкові.

Під керівництвом В. П. Черних здійснено кадровий «прорив» у НФаУ: 31980 р. підготовлено понад 130 докторів наук і близько 650 кандидатів наук. За рейтингом ЮНЕСКО, серед 200 кращих університетів України НФаУ має один із найвищих показників якості науково-педагогічного потенціалу - 94 \%. За останні 15 років у ньому відкрито 13 нових спеціальностей, Інститут підвищення кваліфікації спеціалістів фармації, коледж. у період керування університетом Валентин Петрович забезпечив стабільне фінансове становище ВНЗ, створив ефективну систему соціального захисту співробітників і студентів. НФаУ займає лідерські позиції в Україні, у національному рейтингу перебуває на другому місці серед 18 медичних навчальних закладів і на третьому - серед харківських університетів, є флагманом фармацевтичної освіти серед навчальних закладів країн СНД. Національний фармацевтичний університет нагороджено Почесною грамотою Кабінету Міністрів України за вагомий внесок у розвиток медичної та фармацевтичної науки й освіти. Це університет європейського рівня, визнаний у світі, Є дійсним членом міжнародних фармацевтичних та освітніх асоціацій. у 2013 р. НФаУ приєднався до Великої хартії університетів. Спеціалізований ВНЗ забезпечує комплексну підготовку фахівців високої якості за всіма напрямами фармацевтичної галузі. У його аудиторіях отримали вищу фармацевтичну освіту понад 50 тисяч фахівців, серед яких більше 6 тисяч магістрів фармації для 82 країн світу. Підготовка спеціалістів для зарубіжжя - це вагомий чинник підвищення міжнародного іміджу нашої держави та освіти.

3 метою реалізації державної політики кадрового забезпечення галузі В. П. Черних запропонував систему підготовки фахівців «на місцях» шляхом відкриття мережі 320 фармацевтичних факультетів при медичних ВН3, забезпечення їх науково-педагогічними кадрами, навчально-методичною літературою. В універси-

ISSN 2312-0967. Фармацевтичний часопис. 2015. № 1 
теті здійснюють підготовку науково-педагогічних кадрів для фармацевтичних факультетів ВНЗ, практичної фармації України та зарубіжних країн.

Уперше в системі фармацевтичної освіти України створено навчально-методичні комплекси навчальної літератури з усіх дисциплін обсягом понад 2 тисячі найменувань. Навчальний процес на 100 \% забезпечено навчально-методичною літературою державною та іноземними мовами, якою користуються всі фармацевтичні факультети України та деяких країн СНД. Наукова спадщина університету - це понад 490 підручників і навчальних посібників, 300 монографій, більше 1500 охоронних документів на винаходи. Учені НФаУ розробили і впровадили у виробництво 261 новий лікарський препарат.

В. П. Черних $є$ ініціатором розробки й одним 3 авторів Концепції розвитку фармацевтичної галузі та освіти України, розширення спектра спеціальностей для фармацевтичної галузі, основоположником новітнього напряму в фармаціїфармацевтичної опіки хворих, системи контролю якості ліків, у т. ч. впровадження біоеквівалентності на засадах належної клінічної практики відповідно до світових вимог.

Для підвищення авторитету і визнання на державному рівні фармацевтичної галузі за ініціативою та за безпосередньою участю В.П. Черних в Україні встановлено професійне свято - День фармацевтичного працівника (1999), запроваджено нову державну нагороду - почесне звання заслуженого працівника фармації України (2005), прийнято Етичний кодекс фармацевтичного працівника України (2010), створено першу в світі Фармацевтичну енциклопедію (перше видання - 2005 р., друге 2010 р.). Під безпосереднім керівництвом Валентина Петровича культурна скарбниця Харківщини була збагачена унікальною скульптурною композицією «Фармація у віках», першим у світі пам'ятником фармацевту. В. П. Черних став ідеологом зміцнення галузі та організатором проведення на базі університету V, VI і VII Національних з'їздів фармацевтів України, створення Фармацевтичної асоціації України.

В. П. Черних - видатний учений в галузі органічної хімії, праці якого широко відомі науковій спільноті України і зарубіжжя. Він є автором 1260 наукових праць, серед яких підручник «Органічна хімія» в 3-х томах, удостоєний у 2000 р. Державної премії України в галузі науки і техніки. Це перший підручник для вищої фармацевтичної освіти України. Учений заснував новий науковий напрям - синтез біологічно активних речовин (похідних дикарбонових кислот), створення на їх основі різних гетероциклічних структур і дослідження шляхів циклізації поліфункціо- нальних реагентів в ансамблі гетероциклів. Новизну і пріоритетність його наукових досліджень підтверджують 126 патентів України та Росії, 341 авторське свідоцтво. Валентин Петрович більше 40 років віддав підготовці докторів і кандидатів наук для вищої школи і практичної фармації. За цей час було створено вітчизняну школу хіміківсинтетиків, у рамках якої науковець підготував понад 60 докторів і кандидатів наук, а також (особисто та з учнями) створив 16 лікарських препаратів.

За підсумками багаторічних наукових досліджень у галузі синтезу біологічно активних речовин у 1997 р. професора В. П. Черних було обрано членом-кореспондентом НАН України. В історії фармації України ця подія стала першим прикладом представництва фармації в академічній науці. За наукові досягнення президія академії наук України в 2013 р. нагородила Валентина Петровича Почесним знаком НАНУ.

В. П. Черних - відомий державний і громадський діяч, ініціатор видання 7 наукових журналів ВАК України. Протягом 30 років працював в експертних радах ВАК СРСР та України. На даний час очолює республіканську Проблемну комісію «Фармація» МОЗ України, є головою Науковометодичної комісії з фармації МОН України, членом вченої ради ДП «Державний фармакологічний центр» МОЗ України, членом президії Фармакопейного комітету МОЗ України, членом вченої медичної ради МОЗ України, членом бюро Державного фармакологічного центру з реєстрації ЛЗ і лП, членом секції хімії та хімічної технології Комітету з Державних премій в галузі науки і техніки, членом колегії Держінспекції з контролю якості лікарських препаратів МОЗ України. В. П. Черних - віце-президент Фармацевтичної асоціації України, президент Фармацевтичної асоціації Харківщини. Його обирали депутатом Київської районної ради народних депутатів м. Харкова (1986) і міської ради народних депутатів (1985-1987). У 1999 р. Міжнародний біографічний центр та Американський біографічний інститут визнали В. П. Черних одним із 500 найбільш впливових і видатних учених світу. Валентин Петрович активно займається міжнародною та просвітницькою діяльністю.

Плідна праця та видатні заслуги відомого вченого, педагога, організатора, державного і громадського діяча були неодноразово відзначені державою: нагороджений орденами «Знак Пошани», «Трудового Червоного Прапора», орденами України «За заслуги» I, II, III ступенів, князя Ярослава Мудрого IV i V ступенів, Почесною грамотою Верховної Ради України, почесними грамотами та відзнаками МО3 і МОН України «Відмінник охорони здоров'я», «Відмінник осві-

ISSN 2312-0967. Pharmaceutical review. 2015. № 1 
ти України», «Винахідник СРСР», «Петро Могила», відзнакою Харківської облдержадміністрації «Слобожанська слава», йому присвоєно почесні звання заслуженого винахідника УРСР, заслуженого діяча науки і техніки УРСР. Харківська громадськість обрала В. П. Черних Почесним громадянином м. Харкова.

Науково-педагогічна й академічна громадськість, колектив і студенти Національного фармацевтичного університету, колеги, друзі, учні від щирого серця вітають відомого вченого, талановитого педагога, видатного організатора та реформатора вищої фармацевтичної освіти, невтомного ентузіаста і патріота фармації, який є яскравим прикладом відданого служіння інтересам освіти, науки, здоров'я людей, інтересам нашої славної України.

Нових Вам, Валентине Петровичу, звершень і злетів, невичерпного творчого натхнення та довголіття. 